\title{
CLIENT-CONSULTANT ETHICAL RELATIONSHIP CONSIDERATIONS WITHIN MANAGEMENT CONSULTING
}

\author{
ALYSON SMITH \\ LJ VAN VUUREN \\ DELÉNE VISSER \\ Programme in Industrial Psychology \\ Department of Human Resource Management \\ Rand Afrikaans University
}

\begin{abstract}
Ethical conduct within consulting has become increasingly important since management consulting has developed into an independent profession. The objective of this research was to determine if differences exist in clientconsultant relationship ethics within a defined group of management consultancies in South Africa. A questionnaire was developed to assess ethical behaviour across five dimensions, namely the client consultant relationship, financial and contractual concerns, delivery of expectations, orientation and competence of consultants, and ethics in consultant behaviour. Thirty-nine respondents completed the questionnaire. Significant differences on ethical dimensions in relation to job level, between consulting firms, the level of senior management commitment to ethics and the existence of a code of ethics were obtained.
\end{abstract}

\section{OPSOMMING}

Namate bestuurskonsultasie as ' $\mathrm{n}$ onafhanklike professie ontwikkel het, het etiese optrede binne hierdie professie algaande belangriker geword. Die doel met hierdie navorsing was om vas te stel of daar verskille ten opsigte van etiek tussen bestuurskonsultasie-ondernemings in Suid-Afrika is sover dit die kliënt-konsultantverhouding aangaan. ' $n$ Vraelys is ontwikkel om die etiese dimensie van bestuurskonsultasie oor vyf dimensies te beoordeel, naamlik die kliënt-konsultantverhouding, finansiële oorwegings, voldoening aan verwagtinge, oriëntasie en bevoegheid van konsultante, en die etiese gedrag van konsultante. Nege-en-dertig respondente het die vraelys voltooi. Beduidende verskille in die etiese dimensies ten opsigte van posvlak, die konsultasie-onderneming, die graad van senior bestuur se toegewydheid tot etiek, en die bestaan van 'n etiese kode is gevind.

Trends of globalisation and rapid advancements in business innovation have created new challenges within organisations both globally and locally. This implies that businesses in South Africa need to recognise and identify those trends that impact on them the most, and to then re-assess their ability not only to improve their overall position in terms of world competitiveness, but also to cope with the move to globalisation, at the organisation, group and individual level. Change will continue to accelerate and organisations have been catapulted into a new era where business is fast, ever changing and increasingly competitive. Taffinder (1995) states that there is a necessity for organisations to recognise the capability to adapt to fast radical change and that those organisations that aspire to be the best must be able to lead change.

Weisbord (1994) reiterates the point that organisations are faced with a global revolution with shifts from physical to knowledge work, mechanical to process technologies, manufacturing to service economies, cultural awareness to greater diversity. Changes are inter-related, affecting and interacting with each other through organisational transformation, including a wide number of pertinent issues, not only at the macro level, but also at the micro level. Hammond, Kelly and Thurston (1994) state that mobility, empowerment, teams, cross-training, virtual offices, telecommuting, re-engineering, restructuring, de-layering, outsourcing are changing peoples' lives. As a result of these changes in workforce dynamics, as well as the move to globalisation and international competition, the challenges facing management are further affected by the apparent lack of skills able to manage the types of changes that are required within organisations (Allnutt, 1991). According to De George (1986), this complexity now faced within business has led to the need for greater specialisation and specialised knowledge, which in turn has led to the emergence of new professions.

Requests for copies should be addressed to: LJ van Vuuren, Department of Human Resource Management, RAU University, PO Box 524, Auckland Park, 2006
Also, Kehayas (1999) states that the growth in South Africa itself and the changes required for new skills and expertise within organisations require that the norm is to often call for outside assistance as the best solution. One of the professions emerging from these dynamics is management consulting, where there has been a marked increase both in global and local markets as a direct result of the tumultuous business environment (Arbose, 1987; Batchelor, 1995; Erasmus \& Schepers, 1997; Shay, 1965; Van Rooyen, 1986). Further, South Africa specifically requires strengthened, more widely available, professionally equipped management consulting services, offered by consultants from a wider range of racial and cultural groups (Price, 1991). There is an ongoing debate as to whether management consulting has in fact reached professional status (Erasmus \& Schepers, 1997) in that some argue that management consulting has not achieved independent status from other professions such as engineering and accounting. Despite this opinion however, institutes such as the South African Institute of Chartered Accountants (1992) view management consulting as a separate profession. In recognition of its status as an independent profession, the Institute of Management Consultants (IMC) has been formed. This is a global institution aimed at acting as a certifying body for the profession, to raise the professional standards of management consulting in ethics and performance and to safeguard the interests of their clients (Kehayas, 1999).

\section{Defining management consulting}

In light of this general recognition of management consulting as a profession, consulting has experienced unprecedented growth in a complex environment of change. Wooldridge (1997) notes that companies have learnt to understand the value in buying advice from outside specialists and that the price is relative to the fact that they know that they have access to the same expertise as their competitors. These specialists normally include management consultants who help to effect constructive changes within organisations through the use of 
substantive and process skills. In terms of defining management consulting, it can be described as an independent and objective advisory service provided by qualified individuals to clients, in order to assist them identify and analyse management problems and opportunities (Barcus \& Wilkinson, 1986). Further, Shays (1988) defines management consulting as a profession, the members of which render advice and assistance within ethical standards and on the basis of the competence in the process of management. Therefore, management consulting can best be defined as a professional advisory service, contracted for and provided by specially trained and qualified practitioners, who assist the client organisation in an objective and independent manner to identify and analyse organisational problems, recommend solutions and assist in the implementation of solutions (Allnutt, 1991; Greiner \& Metzger, 1983). This in turn indicates specific roles that the consultant might play within an organisation, including information gathering, analysis, provision of advice and assistance in implementation (Batchelor, 1995). In simple terms, a management consultant can therefore be viewed as a change agent who helps organisations define and achieve their goals, proposes changes and helps to implement (Kehayas, 1999).

In light of this role, consulting has two significant paths of service or delivery; one path is the 'expert' who is able to provide technical specialisation and support to an agency; these types of consultants tend to be experts in focus and directive in mode of delivery. The second path is more generalised and is one involving combined knowledge of social-psychological, cognitive-behavioural, and ecologicalsystems theories and principles (Kehayas, 1999; Parsons, 1996). Also, Block (1981) is of the opinion that consultancies would be forced to become more specialised, that clients would become more demanding and that there would be an increased split between resource and process consulting. However, despite there being two paths to providing services, even if consultancies have a strategy or philosophy around these, the services rendered by management consultants are complicated by their personalised nature (Kubr, 1988). This complexity is further enhanced by the inherent complexities in the interactions that the consultant has with the client organisation.

It is apparent that the delivery of these defined services occur as a direct interaction between the consulting firm, the consultant and the client. The consultant does not generally act from a power base but as a specialist with specific competencies, values and norms. Together with the move to globalisation, there has been an emergence of specified quality and service standards within management consultancies. Many consultancies now have a global approach, which more specifically includes the use of standardised and integrated methodologies for approaching projects and the delivery of work.

Consulting firms can generally be categorised into eight types of firms, namely national general management firms; national accounting firms with consulting units; functionally specialised firms; public sector firms; industry specialised firms; think tanks; regional and local firms; and sole practitioners (Greiner \& Metzger, 1983). In choosing a type of consulting firm, the client will obviously determine the need of the service required, and based on this review, the services available. However, according to Moore (1984) many companies will go immediately to one of the top firms relying often on their reputation and the fact that the big accounting firms (once commonly known as the 'big five') have been given a lot of credit and recognition for reviving companies, introducing new technologies and practices. Generally, these top consulting companies have staff with the necessary competencies, are able to provide a wider range of services and are perceived to adhere to high professional standards. The recipients of consulting services, knowledge and advice are clients, who could either be a department within the client organisation, a work team or the entire organisation; thereby indicating that there is an inherent client-consultant relationship.

According to Allnutt (1991), consulting advice may be given to anyone at any level in the client organisation who bears responsibility and is able to put into action the advice given by the consultant. Therefore, consultants are people who, when asked, agree to use their expertise to help clients narrow the gap between what they have now and what they want or where they want to be in the future (Bellman, 1990). This is reiterated by Harvey and Brown (1996) who describe a consultant as a person attempting to deliberately modify the functioning of the total organisation or one of its major parts in order to bring about improved effectiveness. Ultimately, the consultant is a person in a position to have some influence over an individual, a group, or an organisation, but who has no direct power to make changes or implement programmes (Block, 1981).

\section{The client-consultant relationship}

This delivery of consulting services implies a client-consultant relationship, which is built on the need to address and meet client expectations. It is apparent that within the defined relationship between the client, in other words the recipients of the advice, and consultant, there are potential risks and issues that need to be addressed and agreed upon throughout the consulting process. Bader and Stich (1993) comment that because of the potential variance in scope and complexity of projects, the groundwork needs to be completed carefully, including the political nature of the project and the product or process focus of the project. This groundwork should be addressed as early as possible and more specifically in the initial interactions with the client if possible. Further, the interrelations between product, process and politics have to be managed carefully. Understanding these interrelationships can result in the development of successful client-consultant relationships that are aimed at meeting the client's needs (Erasmus \& Schepers, 1997).

The consulting relationship is, therefore, a focal point of the interaction between consultancy and client, as well as the nature of the interaction or the role to be played by the consultant (Parsons, 1996). As discussed above, the consultant's role is further characterised as being helping, problem solving and process orientated. In light of this and according to Allnutt (1991), clients are interested in building longer relationships with consulting firms in whom they have confidence. Despite this clients often engage the services and pay for the reputation of the major firm, but receive the services of inexperienced consultants employed by these firms (Allnutt, 1991; Greiner \& Metzger, 1983; Shay, 1965). Further, with the increasing demand for consulting type services, increased competition between consultancies for projects has resulted. This often leads to a focus on selling services to the client, finessing the sale and beating the competition, rather than on the real issue of consulting; which as previously defined is aimed at assisting the client to solve problems, to design integrated business systems and assist in the implementation of solutions. As a result, clients often regard consultants with suspicion and contempt as a direct result of unethical behaviour often perceived to be exhibited within the consulting profession.

Ethical considerations in management consulting and the client-consultant relationship

As professionals within this client-consultant relationship, consultants often confront the complexity of ethical dilemmas, including the intrusion of preconceived images of the consultant-client relationship, dangers in the manipulation of 
human behaviour, the issue of achieving congruence between values and behaviour, the possibility of multiple clients, and the issues surrounding advocacy and innovation (Parsons, 1996; Van Rooyen, 1996). Ethical issues stem from a myriad of compromising situations involving breaches of client confidentiality, the scope of services offered, practice expansion and development, billing for services rendered or not rendered, misrepresentation of results, deceptive practices, and legal liability (Allen \& Davis, 1993; De George, 1986). Alleged misconduct and non-delivery within the consulting profession has led to scrutiny and wariness of consultants and the profession in general.

As a result, one can generally define ethics as a systematic attempt, through the use of reason, to make sense of individual and social moral experiences in such a way as to determine the rules that ought to govern human conduct and the values worth pursuing in life (Bowie \& Duska, 1990; De George, 1986). Ethics can further be defined as norms and standards that are used to guide decision-making about morally correct courses of action or behaviour (Allen \& Davis, 1993; Guy, 1990). Businesses expect management consultancies and their consultants, as professionals, to set higher standards of conduct and to enforce a higher level of discipline than what is required of others, including those in their employ (De George, 1989; Van Rooyen, 1996). Also, according to Harvey and Brown (1996), it is important that consultants consider the ethical consequences of various actions and to develop a set of ethical standards to guide them when competing interests collide. However it is not just the consultant that needs to take responsibility for ethical behaviour, but also the consultancy, which as an organisation has a responsibility to develop and enforce a commonly understood, and adhered to, ethical guideline which more often than not would take the form of an ethical code.

Further, uncertainty and growth within business environments has lent itself to the demand and emergence of a wide variety of consultants providing consulting services in a large number of areas. According to Allen and Davis (1993), this has led to diversity in skills, backgrounds and orientations, which has possibly led to an increase in the credibility of consulting. However, this same diversity could potentially lead to a lack of ethical continuity within the consulting profession, which the Institute of Management Consultants is currently attempting to ensure. As a result of this diversity and potential inconsistency, there are numerous ethical considerations for consultants, including the need for the 'ethical consultant' to be competent and skilled, to be aware of operative individual values, demonstrate cultural awareness and sensitivity (Parsons, 1996). Around this are the considerations of confidentiality, informed consent, and professional boundaries within the consultation relationship. Further, according to Parsons (1996), it is possible to group ethical issues into three broad categories, namely those concerning the consultant, those involving the client-consultant relationship and those concerning the process of consulting. However, one can add a fourth category, namely those concerning the responsibility of the consultancy practice.

Ethics concerning the consultant demand that the consultant be competent and has the requisite skills, be aware of the consultancy's operative values and ethics, and have an ability to demonstrate cultural sensitivity (Paine, 1994). This would include aspects such as understanding one's own culture, being aware of the risks of having a single mainstream perspective, and finally understanding and valuing alternate worldviews. The ethical issues involved in the clientconsultant relationship are of such a nature that it is imperative that the consultant remember that the consultation relationship exists for the benefit of the client, the consulting firm, and the consultancy's system, and not for the personal needs or benefits of the consultant (Parsons, 1996). Therefore the direct ethical aspects within this relationship should include gaining informed consent, establishing and maintaining confidentiality, establishing and maintaining professional boundaries, and the utilisation of power and influence within the consultation relationship (Bowie \& Duska, 1990; Guy, 1990; Newman, 1993; Parsons, 1996). The ethical considerations within the consultation process focus on the provision of the services and deliverables contracted from the consultant. Specific ethical aspects include identification of the client, efficacy of the 'treatment' and evaluation included in providing the required services such as specified deliverables within the specified timing and costs. Finally, the ethical considerations around the consulting practice include both the firm's responsibility to develop and appropriately implement guidelines for ethical behaviour, which are obviously driven by management. In essence, management that fails to provide proper leadership and to institute systems that facilitate ethical conduct share responsibility with those that conceive, execute, and knowingly benefit from corporate misdeeds (Paine, 1994; Parsons, 1996). Therefore in essence, the consulting firm and its leadership hold responsibility for initiating, developing and implementing ethical guidelines and supporting systems to facilitate ethical behaviour within their practice.

However, a further important consideration is the premise that consultants are moral individuals with conflicting value systems, as well as members of the consulting profession (Allen \& Davis, 1993; De George, 1986). Ultimately, the choices that the individual makes involve the values and ideals inherent to the individual (Allen \& Davis, 1993; Hegarty \& Simms, 1978), even though the consultant implicitly or explicitly agrees to abide by accepted standards (Shaw, 1991). The choices that a consultant makes are often value judgements between two or more values and making a therefore often involves making an ethical decision (Van Rooyen, 1996).

Values are ultimately core beliefs about what is intrinsically desirable which ultimately give rise to ideals called ethics. According to Guy (1990), ethics refer to standards by which individuals evaluate their own conduct in relation to the conduct of others. As a result, and to the extent that individual values and professional norms should correspond, practising consultants are expected to adhere to a set of high personal values that maintain and exemplify ethical behaviour to other professionals in the field. Also, in a study conducted by Allen and Davis (1993), it was concluded that although consultants can maintain high personal and professional values, these can disintegrate when consultants are faced with dilemmas or ambiguous ethical situations, often with completely ethical people forced by competitive pressures to act unethically (Guy, 1990). This is reiterated by Johannessen Ims (1995), in that consultants are often in a dilemma whenever their values are unacceptable to the client.

As a result, it is important that both the consulting profession and consultancies have formulated ethical and value guidelines to regulate interventions and services provided, in turn providing their consultants with boundaries within which to operate and to guide behaviour. Ethical aspects which need to be governed include gaining informed consent, establishing and maintaining confidentiality, establishing and maintaining professional boundaries, and the utilisation of power and influence within the consultation relationship. However, it is also imperative that although there may be an ethical code in place, consultants still need to be made aware of the level of personal responsibility involved in ethical consulting practices (Guy, 1990; Newman, 1993). Personal responsibility for ethical consulting behaviour also needs to be exhibited by the leadership of the consultancy, which in turn sets an example for the rest of the practice. In light of this, it would appear that certain aspects could potentially affect the level of commitment to ethical behaviour within the consulting profession, including managements' commitment to ethical behaviour, the existence of a formal ethical code that is implemented appropriately, job level within 
the practice, the culture of the organisation and the number of years the consultant has been working in the profession.

It can be concluded from the importance placed on ethical aspects of this client-consultant relationship in the literature available and through discussions with experts in the field, that in essence more research is necessary around ethics specifically within the management consulting profession. Further, the fact that during the research the researchers realised that although there is an abundance of literature on general ethics and business ethics, there is not extensive research conducted on ethics specifically related to management consulting. As a result, this research article's principal objective is to examine the client-consultant relationship from the consultant's perspective in terms of potential ethical issues. These potential issues will be examined from the perspective that ethical issues can be categorised into those that involve the consultant, those that surround the client-consultant relationship, those that affect the process of consulting and those resulting from the consulting practice.

In relation to the above-mentioned categories, it can be concluded from the literature reviewed, that there are numerous ethical considerations surrounding the client-consultant relationship. These can be grouped into five broad categories or dimensions, namely:

- Ethics in consultant behaviour, which relates to the existence and enforcement of codes of ethics, legal liability and the level of ethical issues faced by consultants;

- Financial and contractual concerns, which includes contractual, financial and scoping aspects in relation to the delivery of services;

- Client-consultant relationship, which refers to the direct relationship with the client including such aspects as trust, preconceived ideas, and confidentiality;

- Orientation and competence of consultants, which refers to both ethical and methodology training provided to consultants, the allocation of appropriately competent people to projects, performance management and the enforcement or repercussions of non-ethical behaviour; and

- Delivery of expectations, which relates to the ethical delivery of services to the client versus a primary focus on benefits to the consultancy.

Examples of questions per category are included in Table 1. Further, each of these categories can be assessed in terms of different consultancies, job levels, tenure, the existence of an ethical code within the consultancy and the level of commitment of senior management, all of which may have an impact of the ethics within the organisation and on consultant behaviour.

In meeting the principal objective of this study, it will examine, from the consultant's perspective, perceived ethical behaviour of consultants within each of these broad categories. Due to the specific nature of consultancies, for the purpose of this study, the objective will be examined within the 'accounting firms with consulting units'. From the objective stated above the following hypotheses with regard to consulting ethics variables or dimensions, namely client consultant relationship, financial and contractual concerns, delivery of expectations, orientation and competence of consultants, and ethics in consultant behaviours, were stated:

There are statistically significant differences on the respective dimensions of ethics:

Hypothesis 1: Between consulting firms.

Hypothesis 2: Across job levels.

Hypothesis 3: Across levels of senior management commitment to ethics.

Hypothesis 4: Whether a code of ethics exists and is used.

Hypothesis 5: Across number of years as a consultant.

TABLE 1

EXAMPLES OF ITEMS PER CATEGORY

\begin{tabular}{|c|c|}
\hline Dimension & Items \\
\hline Ethics in consulting & $\begin{array}{l}\text { - Confidentiality is a key consideration when } \\
\text { setting up project infrastructures and } \\
\text { administrative procedures } \\
\text { - Ethical conduct can be enforced with the us }\end{array}$ \\
\hline
\end{tabular}
a code of ethics

- Membership of the consulting profession requires one to compromise one's own ethics

- There should be a code of ethics for the consulting profession

Financial and contractual concerns

- The scope of the project is clearly stated in the contract negotiated with the client

- When clients are billed, there is a clear breakdown in terms of out-of-pocket expenses

- Higher fees can be charged for work provided based on the fact that the client is contracting the services of a global consultancy

- Ethical parameters are implicit in the contractual agreements with clients

Client-consultant relationship

Orientation and competence of consultants

- A clearly defined and mutually understood project scope is needed to develop strong clientconsultant relationships

- Project conclusions and recommendations made are dependent on whether more work can be gained from the client

- Client management and staff have preconceived ideas of consultants

- There are different ethical standards for different clients

- There is an element of trust inherent in the client-consultant relationship

- There are specified performance standards for all consultants on projects

- Ethics is discussed as part of the induction training at the consultancy

- Junior consultants receive relevant training before consulting on a project

- Disciplinary measures are taken against consultants that do not adhere to the required ethics

Delivery of expectations

- This consultancy uses tried and tested methodologies in projects

- Sometimes only part of the data in a study is reported because the client may not like the results

- Work is sold that may not necessarily bring benefits to the client, but will bring in profits to the consultancy

\section{METHOD}

\section{Respondents}

The population was identified as all levels of consulting professionals including consultants, senior consultants, principal consultants/ project managers and senior management (consisting of directors, associate directors and partners). A questionnaire was developed and distributed to a sample of consultants within the selected group of consultancies, namely from the 'national accounting firms with consulting units' group of consultancies in South Africa. The sample excluded independent consultants, smaller or independent consulting firms and internal consultants. In general, these larger consulting firms handle longer-term projects involving larger teams and more complex client relationships than the smaller consultancies. Respondents were chosen according to their availability at the time.

The 'consultant' sample included men and women from various consulting levels with different levels of qualifications and varying years of experience. Approximately 120 consultants were selected in these consultancies, where the consultancies distributed the questionnaires themselves, with responses emailed to the authors of this article. Difficulties with distribution contributed to the poor response rate, including aspects such as the fact that most consultants are at client sites and the difficulty in contacting these consultants. A total of 39 (32.50\% response 
rate) consulting staff responded, despite repeated attempts by the researchers to get more questionnaires returned. These attempts included emailing directly to people rather than relying on the consultancies for distribution, and re-distributing questionnaires periodically over a nine-month period.

A summary of the biographical composition of the sample is provided in Table 2. Due to the low response rates from Consulting Firms C and D, only Consulting Firms A and B were used for comparative analyses. The majority of respondents either had worked in consulting for less than four years $(\mathrm{N}=16)$ or more than 7 years $(\mathrm{N}=13)$, with a mean number of years in the consulting profession of 5.54 years. The sample indicated a marginal leaning towards female respondents $(\mathrm{N}=23)$, with male respondents accounting for $41 \%$ of the sample $(\mathrm{N}=16)$. In terms of job level, $59.0 \%$ of the respondents $(\mathrm{N}=24)$ were senior consultants (Level D) and consultants (Level B); with 10.3\% of the sample being from the senior management or A level $(\mathrm{N}=4)$ and $30.8 \%$ from the principal consultant/project management or $\mathrm{C}$ level $(\mathrm{N}=11)$. The average age of the respondents was 34 years, with the range in age from 23 years to 51 years.

TABLE 2

DESCRIPTIVE STATISTICS OF THE SAMPLE

\begin{tabular}{llrrrr}
\hline Variable & & N & $\%$ & M & SD \\
\hline Consulting Firm & A & 20 & 51,3 & & \\
& B & 15 & 38,5 & & \\
& C & 3 & 7,7 & & \\
Job Level & D & 1 & 2,6 & & \\
& A & 4 & 10,3 & & \\
B & 12 & 30,8 & & \\
Number of years & C 4 years & 16 & 41,0 & 5,54 & \\
as a consultant & 4 to $<$ years & 6 & 15,4 & & \\
& D & 12 & 30,8 & & \\
Gender & Mears & 13 & 33,3 & & \\
& Missing & 4 & 10,3 & & \\
Male & 16 & 41,0 & & \\
Age & Female & 23 & 59,0 & & \\
Number of years with & & & & & \\
current company & & & & & \\
\hline
\end{tabular}

\section{Measuring instrument}

For the purpose of this study a self-administered questionnaire was developed that measured the degree of importance of each item to consulting. The respondents were requested to comment both on items regarding their own ethics, as well as items regarding the consultant-client relationship, the consulting process and the consulting practice. In the main section of the questionnaire, which focused on gaining consultant perceptions of ethical behaviour, a 7-point Likert scale was used to measure the importance of each of the identified items (i.e. Not important at all - Of critical importance).

The questionnaire consisted of a number of sections, including:

Section 1: Biographical section that required information pertaining to tenure, job level, education, gender, age and average number of projects in which the consultant was involved.

Section 2: Ethical Standards which focused on gathering information about the firm's senior management commitment to ethics and the existence of a Code of Ethics.

Section 3: Ethical Factors in Consulting, focused on gathering detailed information about common ethical issues to the profession of consulting and consultants regarding five dimensions, namely the clientconsultant relationship, financial and contractual concerns, delivery of expectations, orientation and competence of consultants, and ethics in consultant behaviour.

Each questionnaire was accompanied by a cover letter detailing the objectives of the study, as well as stressing the voluntary nature and confidentiality of the information obtained.

\section{RESULTS}

All the analyses were performed on section three of the measuring instrument. Pearson product-moment correlation coefficients were calculated to determine the strength, direction and significance of the correlations between the five ethical dimensions, namely ethics in consultant behaviour, financial and contractual concerns, client-consultant relationship, orientation and competence of consultants, and delivery of expectations. High and significant ( $p<0.01$ ), positive correlations existed between all the dimensions, as indicated in Table 3.

TABle 3

INTERCORRELATIONS BETWEEN THE FIVE ETHICAL DIMENSIONS

\begin{tabular}{|c|c|c|c|c|c|c|}
\hline Dimensions & & $\begin{array}{r}\text { Client- consultant } \\
\text { relationship }\end{array}$ & $\begin{array}{r}\text { Financial and contractual } \\
\text { concerns }\end{array}$ & $\begin{array}{r}\text { Delivery of } \\
\text { expectations }\end{array}$ & $\begin{array}{r}\text { Orientation and } \\
\text { competence of consultants }\end{array}$ & $\begin{array}{r}\text { Ethics in consultant } \\
\text { behaviour }\end{array}$ \\
\hline $\begin{array}{l}\text { Client } \\
\text { consultant } \\
\text { relationship }\end{array}$ & $\begin{array}{l}\text { Pearson } \\
\text { correlation } \\
\mathrm{p}(2 \text {-talied }) \\
\mathrm{N}\end{array}$ & $\begin{array}{r}1.00 \\
39\end{array}$ & & & & \\
\hline $\begin{array}{l}\text { Financial and } \\
\text { contractual } \\
\text { concerns }\end{array}$ & $\begin{array}{l}\text { Pearson } \\
\text { correlation } \\
\mathrm{p}(2 \text {-talied }) \\
\mathrm{N}\end{array}$ & $\begin{array}{r}0.60 \\
.000 \\
38\end{array}$ & $\begin{array}{r}1.00 \\
38\end{array}$ & & & \\
\hline $\begin{array}{l}\text { Delivery of } \\
\text { expectations }\end{array}$ & $\begin{array}{l}\text { Pearson } \\
\text { correlation } \\
\mathrm{p}(2 \text {-talied }) \\
\mathrm{N}\end{array}$ & $\begin{array}{r}0.75 \\
.000 \\
38\end{array}$ & $\begin{array}{r}0.61 \\
.000 \\
37\end{array}$ & $\begin{array}{r}1.00 \\
38\end{array}$ & & \\
\hline $\begin{array}{l}\text { Orientation } \\
\text { and } \\
\text { competence } \\
\text { of consultants }\end{array}$ & $\begin{array}{l}\text { Pearson } \\
\text { correlation } \\
\mathrm{p}(2 \text {-talied }) \\
\mathrm{N}\end{array}$ & $\begin{array}{r}0.51 \\
.001 \\
38\end{array}$ & $\begin{array}{r}0.66 \\
.000 \\
37\end{array}$ & $\begin{array}{r}0.46 \\
.004 \\
37\end{array}$ & $\begin{array}{r}1.00 \\
38\end{array}$ & \\
\hline $\begin{array}{l}\text { Ethics in } \\
\text { consultant } \\
\text { behaviour }\end{array}$ & $\begin{array}{l}\text { Pearson } \\
\text { correlation } \\
\mathrm{p}(2 \text {-talied }) \\
\mathrm{N}\end{array}$ & $\begin{array}{r}0.68 \\
.000 \\
38\end{array}$ & $\begin{array}{r}0.58 \\
.000 \\
38\end{array}$ & $\begin{array}{r}0.53 \\
.001 \\
37\end{array}$ & $\begin{array}{r}0.74 \\
.000 \\
37\end{array}$ & $\begin{array}{r}1.00 \\
38\end{array}$ \\
\hline
\end{tabular}


Means, standard deviations, and internal consistency reliabilities (Cronbach alpha) for all the ethical dimensions are presented in Table 4.

TABLE 4

DESCRIPTIVE STATISTICS AND INTERNAL CONSISTENCY RELIABILITIES FOR THE ETHICS DIMENSIONS

\begin{tabular}{lccccc}
\hline Dimensions & N & $\begin{array}{c}\text { Number } \\
\text { of items }\end{array}$ & M & SD & $\begin{array}{c}\text { Cronbach } \\
\text { alpha }\end{array}$ \\
\hline $\begin{array}{l}\text { Total sample } \\
\begin{array}{l}\text { Client-consultant } \\
\text { relationship }\end{array}\end{array}$ & 39 & 71 & 4.84 & 0.56 & 0.93 \\
$\begin{array}{l}\text { Financial and } \\
\text { contractual concerns }\end{array}$ & 38 & 14 & 4.47 & 0.67 & 0.72 \\
$\begin{array}{l}\text { Delivery of expectations } \\
\begin{array}{l}\text { Orientation and } \\
\text { competence of consultants }\end{array}\end{array}$ & 38 & 10 & 5.70 & 0.81 & 0.81 \\
$\begin{array}{l}\text { Ethics in consultant } \\
\text { behaviour }\end{array}$ & 38 & 15 & 4.18 & 1.02 & 0.90 \\
\hline
\end{tabular}

Due to the small sample size, nonparametric tests were used to test the various hypotheses. The first test compared Consulting Firm A with Consulting Firm B in relation to the defined dimensions. Due to few respondents from the Consulting Firms $\mathrm{C}$ and $\mathrm{D}$, these were excluded from this comparison. The MannWhitney $U$ test, for two independent samples, was administered across each ethical dimension for these two consulting firms. From the results, it is apparent that Consulting Firm B showed higher mean ranks than Consulting Firm A and therefore appears more ethical across all the dimensions, the results were statistically significant only with regard to the ethical dimension of ethics in consultant behaviour. The results are presented in Table 5

TABLE 5

COMPARISON OF ETHICS DIMENSIONS BETWEEN DIFFERENT CONSULTING FIRMS

\begin{tabular}{|c|c|c|c|c|c|c|c|}
\hline Dimensions & \multicolumn{2}{|c|}{ Company } & $\mathbf{N}$ & M & SD & $\begin{array}{c}\text { SE } \\
\text { (Mean) }\end{array}$ & $\begin{array}{c}\text { Mean } \\
\text { rank }\end{array}$ \\
\hline \multirow{2}{*}{$\begin{array}{l}\text { Client consultant } \\
\text { relationship }\end{array}$} & \multirow{2}{*}{\multicolumn{2}{|c|}{$\begin{array}{l}\text { Consulting Firm A } \\
\text { Consulting Firm B }\end{array}$}} & 15 & 4.96 & 0.45 & 0.12 & 14.93 \\
\hline & & & 20 & 5.26 & 0.53 & 0.12 & 20.30 \\
\hline \multirow{2}{*}{$\begin{array}{l}\text { Financial and } \\
\text { contractual } \\
\text { concerns }\end{array}$} & \multirow{2}{*}{\multicolumn{2}{|c|}{$\begin{array}{l}\text { Consulting Firm A } \\
\text { Consulting Firm B }\end{array}$}} & 15 & 4.31 & 0.65 & 0.17 & 14.80 \\
\hline & & & 19 & 4.56 & 0.59 & 0.14 & 19.63 \\
\hline \multirow{2}{*}{$\begin{array}{l}\text { Delivery of } \\
\text { expectations }\end{array}$} & \multirow{2}{*}{\multicolumn{2}{|c|}{$\begin{array}{l}\text { Consulting Firm A } \\
\text { Consulting Firm B }\end{array}$}} & 15 & 5.43 & 0.84 & 0.22 & 14.47 \\
\hline & & & 19 & 5.85 & 0.74 & 0.17 & 19.89 \\
\hline \multirow{2}{*}{$\begin{array}{l}\text { Orientation and } \\
\text { competence of } \\
\text { consultants }\end{array}$} & \multirow{2}{*}{\multicolumn{2}{|c|}{$\begin{array}{l}\text { Consulting Firm A } \\
\text { Consulting Firm B }\end{array}$}} & 15 & 3.95 & 1.12 & 0.29 & 15.20 \\
\hline & & & 19 & 4.26 & 0.81 & 0.19 & 19.32 \\
\hline \multirow{3}{*}{$\begin{array}{l}\text { Ethics in } \\
\text { consultant } \\
\text { behaviour }\end{array}$} & \multirow{2}{*}{\multicolumn{2}{|c|}{$\begin{array}{l}\text { Consulting Firm A } \\
\text { Consulting Firm B }\end{array}$}} & 15 & 4.65 & 0.62 & 0.16 & 13.60 \\
\hline & & & 19 & 5.13 & 0.49 & 0.11 & 20.58 \\
\hline & $\begin{array}{r}\text { Client- } \\
\text { consultant } \\
\text { elationship }\end{array}$ & $\begin{array}{r}\text { Financial } \\
\text { and } \\
\text { contractual } \\
\text { concerns }\end{array}$ & \multicolumn{2}{|c|}{$\begin{array}{r}\text { Delivery of } \\
\text { expectations }\end{array}$} & \multicolumn{2}{|c|}{$\begin{array}{r}\text { Orientation } \\
\text { and } \\
\text { competence } \\
\text { of } \\
\text { consultants }\end{array}$} & $\begin{array}{l}\text { Ethics in } \\
\text { onsultant } \\
\text { ehaviour }\end{array}$ \\
\hline \multirow{2}{*}{$\begin{array}{l}\text { Mann-Whitney U } \\
\text { p (2-tailed) }\end{array}$} & 104.00 & 102.00 & & 97.00 & \multicolumn{2}{|c|}{108.00} & 84.00 \\
\hline & 0.125 & 0.160 & & 0.113 & \multicolumn{2}{|c|}{0.230} & 0.042 * \\
\hline
\end{tabular}

$* p<0.05$
The relation between length of time in consulting and ethics was tested using the Kruskal-Wallis test and is presented Table 6. It is apparent that length of time in consulting does not affect perceptions of ethical behaviour in any of the dimensions.

TABLE 6

COMPARISON OF THE ETHICS DIMENSIONS FOR YEARS IN THE PROFESSION OF CONSULTING

\begin{tabular}{|c|c|c|c|c|c|c|c|}
\hline Dimensions & \multicolumn{2}{|c|}{$\begin{array}{l}\text { Years in } \\
\text { consulting }\end{array}$} & $\mathrm{N}$ & M & SD & SE & $\begin{array}{c}\text { Mean } \\
\text { rank }\end{array}$ \\
\hline \multirow{4}{*}{$\begin{array}{l}\text { Client consultant } \\
\text { relationship }\end{array}$} & \multicolumn{2}{|c|}{$<4$ years } & 16 & 5.13 & 0.61 & 0.15 & 16.75 \\
\hline & \multicolumn{2}{|c|}{4 to $<7$ years } & 6 & 5.12 & 0.30 & 0.12 & 16.75 \\
\hline & \multicolumn{2}{|c|}{$\geq 7$ years } & 13 & 5.29 & 0.55 & 0.15 & 20.12 \\
\hline & \multicolumn{2}{|l|}{ Total } & 35 & 5.20 & 0.54 & 0.09 & \\
\hline \multirow{4}{*}{$\begin{array}{l}\text { Financial and } \\
\text { contractual } \\
\text { concerns }\end{array}$} & \multicolumn{2}{|c|}{$<4$ years } & 16 & 4.53 & 0.71 & 0.18 & 16.91 \\
\hline & \multicolumn{2}{|c|}{4 to $<7$ years } & 5 & 4.53 & 0.68 & 0.30 & 17.70 \\
\hline & \multicolumn{2}{|c|}{$\geq 7$ years } & 13 & 4.55 & 0.67 & 0.19 & 18.15 \\
\hline & \multicolumn{2}{|l|}{ Total } & 34 & 4.54 & 0.67 & 0.12 & \\
\hline \multirow{4}{*}{$\begin{array}{l}\text { Delivery of } \\
\text { expectations }\end{array}$} & & 15 & 5.74 & 0.94 & 0.24 & 17.70 \\
\hline & \multicolumn{2}{|c|}{4 to $<7$ years } & 6 & 5.37 & 0.54 & 0.22 & 10.92 \\
\hline & \multicolumn{2}{|c|}{$\geq 7$ years } & 13 & 5.94 & 0.80 & 0.22 & 20.31 \\
\hline & \multicolumn{2}{|l|}{ Total } & 34 & 5.75 & 0.83 & 0.14 & \\
\hline \multirow{4}{*}{$\begin{array}{l}\text { Orientation and } \\
\text { competence of } \\
\text { consultants }\end{array}$} & \multicolumn{2}{|c|}{$<4$ years } & 15 & 4.69 & 1.00 & 0.26 & 21.37 \\
\hline & \multicolumn{2}{|c|}{4 to $<7$ years } & 6 & 3.81 & 1.07 & 0.44 & 13.17 \\
\hline & \multicolumn{2}{|c|}{$\geq 7$ years } & 13 & 4.03 & 0.93 & 0.26 & 15.04 \\
\hline & \multicolumn{2}{|l|}{ Total } & 34 & 4.28 & 1.03 & 0.18 & \\
\hline \multirow{4}{*}{$\begin{array}{l}\text { Ethics in } \\
\text { consultant } \\
\text { behaviour }\end{array}$} & & 16 & 5.12 & 0.56 & 0.14 & 19.91 \\
\hline & \multicolumn{2}{|c|}{4 to $<7$ years } & 5 & 4.68 & 0.38 & 0.17 & 11.20 \\
\hline & \multicolumn{2}{|c|}{$\geq 7$ years } & 13 & 4.93 & 0.72 & 0.20 & 16.96 \\
\hline & \multicolumn{2}{|l|}{ Total } & 34 & 4.98 & 0.61 & 0.11 & \\
\hline & $\begin{array}{r}\text { Client- } \\
\text { consultant } \\
\text { elationship }\end{array}$ & $\begin{array}{r}\text { Financial } \\
\text { and } \\
\text { contractual } \\
\text { concerns }\end{array}$ & \multicolumn{2}{|c|}{$\begin{array}{r}\text { Delivery of } \\
\text { expectations }\end{array}$} & \multicolumn{2}{|c|}{$\begin{array}{r}\text { Orientation } \\
\text { and } \\
\text { competence } \\
\text { of } \\
\text { consultants }\end{array}$} & $\begin{array}{r}\text { Ethics in } \\
\text { consultant } \\
\text { behaviour }\end{array}$ \\
\hline \multirow{2}{*}{$\begin{array}{l}\text { Chi-Square } \\
\text { df }\end{array}$} & 0.88 & 0.12 & & 3.69 & \multicolumn{2}{|c|}{4.18} & 2.98 \\
\hline & 2 & 2 & & 2 & \multicolumn{2}{|r|}{2} & 2 \\
\hline p (2-tailed) & 0.643 & 0.944 & & 0.158 & \multicolumn{2}{|c|}{0.123} & 0.225 \\
\hline
\end{tabular}

A comparison in terms of job level and the five ethical dimensions was conducted using the Kruskal-Wallis test; the results of which are presented in Table 7 . The job levels were grouped together into four categories as follows: A - Senior/ Executive management; B - Consultant; C - Principal consultants/Project managers; and D Senior Consultant. There was a significant relation between job level within the financial and contractual concerns and the orientation and competence of consultants dimensions. 
TABLE 7

COMPARISON OF ETHICS DIMENSIONS BETWEEN JOB LEVELS

\begin{tabular}{|c|c|c|c|c|c|c|c|}
\hline Dimensions & Job level & & $\mathbf{N}$ & M & SD & SE & $\begin{array}{c}\text { Mean } \\
\text { rank }\end{array}$ \\
\hline $\begin{array}{l}\text { Client consultant } \\
\text { relationship }\end{array}$ & $\begin{array}{l}\text { A } \\
\text { B } \\
\text { C } \\
\text { D } \\
\text { Total }\end{array}$ & & \begin{tabular}{c|c}
4 \\
12 \\
12 \\
11 \\
39
\end{tabular} & $\begin{array}{l}5.52 \\
5.02 \\
5.17 \\
5.19 \\
5.16\end{array}$ & $\begin{array}{l}0.46 \\
0.53 \\
0.66 \\
0.40 \\
0.53\end{array}$ & $\begin{array}{l}0.23 \\
0.15 \\
0.19 \\
0.12 \\
0.09\end{array}$ & $\begin{array}{l}27.00 \\
16.38 \\
20.88 \\
20.45\end{array}$ \\
\hline $\begin{array}{l}\text { Financial and } \\
\text { contractual } \\
\text { concerns }\end{array}$ & $\begin{array}{l}\text { A } \\
\text { B } \\
\text { C } \\
\text { D } \\
\text { Total }\end{array}$ & & \begin{tabular}{c|}
4 \\
12 \\
12 \\
10 \\
38
\end{tabular} & $\begin{array}{l}4.71 \\
4.79 \\
4.30 \\
4.19 \\
4.47\end{array}$ & $\begin{array}{l}0.36 \\
0.70 \\
0.67 \\
0.58 \\
0.67\end{array}$ & $\begin{array}{l}0.18 \\
0.21 \\
0.19 \\
0.18 \\
0.11\end{array}$ & $\begin{array}{l}26.25 \\
24.96 \\
16.83 \\
13.45\end{array}$ \\
\hline $\begin{array}{l}\text { Delivery of } \\
\text { expectations }\end{array}$ & $\begin{array}{l}\text { A } \\
\text { B } \\
\text { C } \\
\text { D } \\
\text { Total }\end{array}$ & & \begin{tabular}{c|c}
4 \\
11 \\
12 \\
11 \\
38
\end{tabular} & $\begin{array}{l}6.10 \\
5.52 \\
5.84 \\
5.56 \\
5.70\end{array}$ & $\begin{array}{l}0.42 \\
1.00 \\
0.82 \\
0.68 \\
0.81\end{array}$ & $\begin{array}{l}0.21 \\
0.30 \\
0.24 \\
0.20 \\
0.13\end{array}$ & $\begin{array}{l}25,13 \\
17.82 \\
21.71 \\
16.73\end{array}$ \\
\hline $\begin{array}{l}\text { Orientation and } \\
\text { competence of } \\
\text { consultants }\end{array}$ & $\begin{array}{l}\text { A } \\
\text { B } \\
\text { C } \\
\text { D } \\
\text { Total }\end{array}$ & & $\begin{array}{c}4 \\
11 \\
12 \\
11 \\
38\end{array}$ & $\begin{array}{l}4.97 \\
4.73 \\
3.81 \\
3.75 \\
4.18\end{array}$ & $\begin{array}{l}0.60 \\
1.22 \\
0.79 \\
0.79 \\
1.02\end{array}$ & $\begin{array}{l}0.30 \\
0.37 \\
0.23 \\
0.24 \\
0.17\end{array}$ & $\begin{array}{l}28.38 \\
25.00 \\
15.63 \\
15.00\end{array}$ \\
\hline $\begin{array}{l}\text { Ethics in } \\
\text { consultant } \\
\text { behaviour }\end{array}$ & $\begin{array}{l}\text { A } \\
\text { B } \\
\text { C } \\
\text { D } \\
\text { Total }\end{array}$ & & \begin{tabular}{c|}
4 \\
12 \\
12 \\
10 \\
38
\end{tabular} & $\begin{array}{l}5.47 \\
5.06 \\
4.87 \\
4.69 \\
4.95\end{array}$ & $\begin{array}{l}0.28 \\
0.56 \\
0.66 \\
0.52 \\
0.59\end{array}$ & $\begin{array}{l}0.14 \\
0.16 \\
0.19 \\
0.16 \\
0.10\end{array}$ & $\begin{array}{l}30.25 \\
21.75 \\
17.92 \\
14.40\end{array}$ \\
\hline re & $\begin{array}{r}\text { Client- } \\
\text { consultant } \\
\text { elationship }\end{array}$ & $\begin{array}{r}\text { Financial } \\
\text { and } \\
\text { contractual } \\
\text { concerns }\end{array}$ & \multicolumn{2}{|c|}{$\begin{array}{r}\text { Delivery of } \\
\text { expectations }\end{array}$} & \multicolumn{2}{|c|}{$\begin{array}{r}\begin{array}{r}\text { Orientation } \\
\text { and } \\
\text { competence } \\
\text { of } \\
\text { consultants }\end{array}\end{array}$} & $\begin{array}{l}\text { Ethics in } \\
\text { onsultant } \\
\text { behaviour }\end{array}$ \\
\hline Chi-Square & 2.82 & 8.05 & & 2.45 & & 53 & 6.60 \\
\hline df & 3 & 3 & & 3 & & 3 & 3 \\
\hline $\mathrm{p}$ & 0.421 & $0.045^{*}$ & & 0.485 & 0.0 & & 0.086 \\
\hline
\end{tabular}

${ }^{*} \mathrm{p}<0.05$

From the results presented in Table 7 , in terms of the financial ethical aspects of consulting, both the senior management level and the consultant level showed higher mean ranks than the senior and principal consultant levels, and as a result appeared more ethical. These results however cannot be tested for statistical significance, because post-hoc procedures are not available. Further, the senior management and consultant levels also showed higher mean ranks than the senior and principal consultant levels on the orientation and competence of consultants dimension, and therefore appeared to be more ethically focused in terms of this dimension.

In terms of the level of commitment of senior management to ethics within their consulting practices in relation to the ethics included in each of the dimensions (see Table 8), the Mann-Whitney $U$ test was used. There were significant differences in all the ethical dimensions, indicating that where there is high senior management commitment to ethics, the perceptions and practice of ethical behaviour is higher than where such commitment is lacking.
TABLE 8

COMPARISON OF SENIOR MANAGEMENT COMMITMENT TO ETHICS WITHIN THE ETHICS DIMENSIONS

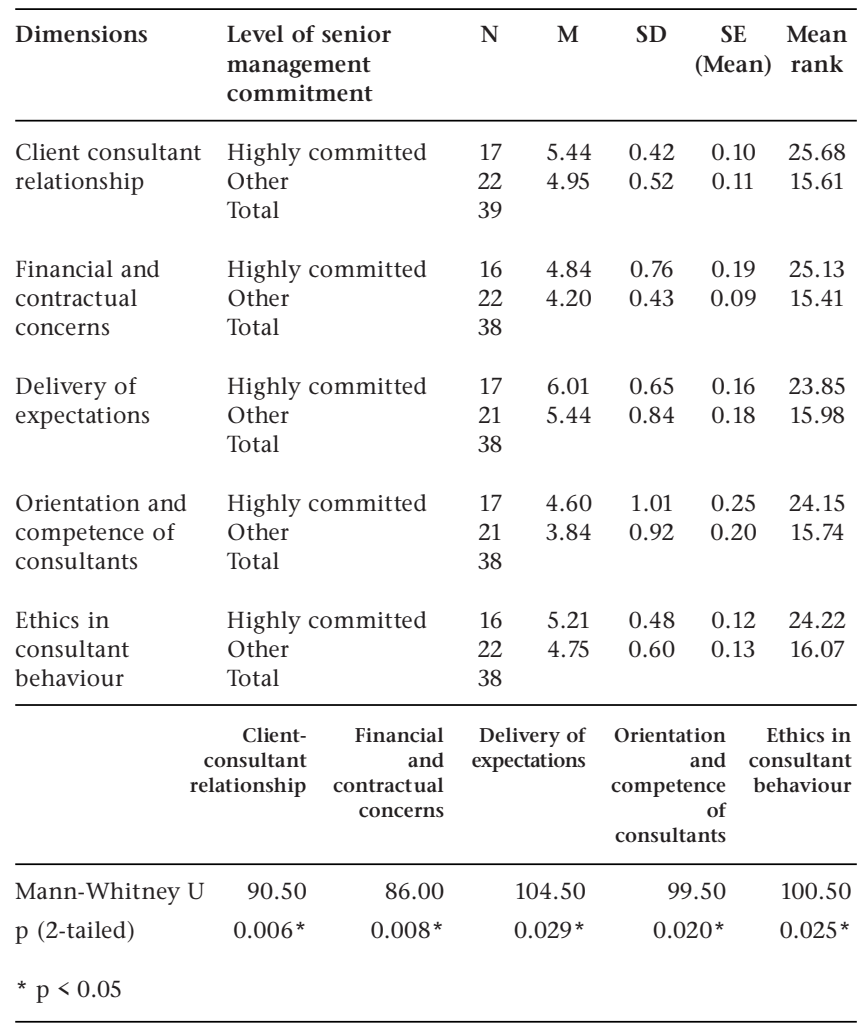

The analysis, using the Kruskal-Wallis test, of the existence of ethical codes within the consulting firms in relation to the five ethical dimensions, is presented in Table 9. It is apparent that where a code of ethics exists, the orientation and competence of consultants, in terms of ethical behaviour, is more advanced. However, in terms of all the other dimensions there were no significant differences.

TABLE 9

COMPARISON OF THE EXISTENCE OF ETHICAL CODES IN RELATION TO THE ETHICS DIMENSIONS

\begin{tabular}{|c|c|c|c|c|c|c|}
\hline Dimensions & $\begin{array}{l}\text { Consultancy } \\
\text { employment of a } \\
\text { code of ethics }\end{array}$ & $\mathbf{N}$ & $\mathbf{M}$ & SD & $\begin{array}{c}\text { SE } \\
\text { (Mean) }\end{array}$ & $\begin{array}{c}\text { Mean } \\
\text { rank }\end{array}$ \\
\hline $\begin{array}{l}\text { Client consultant } \\
\text { relationship }\end{array}$ & $\begin{array}{l}\text { Yes } \\
\text { No } \\
\text { Don't know } \\
\text { Total }\end{array}$ & $\begin{array}{l}14 \\
10 \\
15 \\
39\end{array}$ & $\begin{array}{l}5.24 \\
5.18 \\
5.08 \\
5.16\end{array}$ & $\begin{array}{l}0.57 \\
0.53 \\
0.53 \\
0.53\end{array}$ & $\begin{array}{l}0.15 \\
0.17 \\
0.14 \\
0.09\end{array}$ & $\begin{array}{l}21.29 \\
20.50 \\
18.47\end{array}$ \\
\hline $\begin{array}{l}\text { Financial and } \\
\text { contractual } \\
\text { concerns }\end{array}$ & $\begin{array}{l}\text { Yes } \\
\text { No } \\
\text { Don't know } \\
\text { Total }\end{array}$ & $\begin{array}{l}13 \\
10 \\
15 \\
38\end{array}$ & $\begin{array}{l}4.71 \\
4.47 \\
4.26 \\
4.47\end{array}$ & $\begin{array}{l}0.85 \\
0.52 \\
0.52 \\
0.67\end{array}$ & $\begin{array}{l}0.24 \\
0.17 \\
0.13 \\
0.11\end{array}$ & $\begin{array}{l}22.31 \\
20.45 \\
16.43\end{array}$ \\
\hline $\begin{array}{l}\text { Delivery of } \\
\text { expectations }\end{array}$ & $\begin{array}{l}\text { Yes } \\
\text { No } \\
\text { Don't know } \\
\text { Total }\end{array}$ & $\begin{array}{l}13 \\
10 \\
15 \\
38\end{array}$ & $\begin{array}{l}5.83 \\
5.93 \\
5.42 \\
5.70\end{array}$ & $\begin{array}{l}0.93 \\
0.55 \\
0.80 \\
0.81\end{array}$ & $\begin{array}{l}0.26 \\
0.17 \\
0.21 \\
0.13\end{array}$ & $\begin{array}{l}21.62 \\
22.45 \\
15.70\end{array}$ \\
\hline $\begin{array}{l}\text { Orientation and } \\
\text { competence of } \\
\text { consultants }\end{array}$ & $\begin{array}{l}\text { Yes } \\
\text { No } \\
\text { Don't know } \\
\text { Total }\end{array}$ & $\begin{array}{l}14 \\
10 \\
14 \\
38\end{array}$ & $\begin{array}{l}4.86 \\
3.95 \\
3.66 \\
4.18\end{array}$ & $\begin{array}{l}0.94 \\
1.04 \\
0.71 \\
1.02\end{array}$ & $\begin{array}{l}0.25 \\
0.33 \\
0.19 \\
0.17\end{array}$ & $\begin{array}{l}27.07 \\
16.60 \\
14.00\end{array}$ \\
\hline $\begin{array}{l}\text { Ethics in } \\
\text { consultant } \\
\text { behaviour }\end{array}$ & $\begin{array}{l}\text { Yes } \\
\text { No } \\
\text { Don't know } \\
\text { Total }\end{array}$ & $\begin{array}{l}13 \\
10 \\
15 \\
38\end{array}$ & $\begin{array}{l}5.24 \\
4.92 \\
4.71 \\
4.95\end{array}$ & $\begin{array}{l}0.48 \\
0.58 \\
0.60 \\
0.59\end{array}$ & $\begin{array}{l}0.13 \\
0.18 \\
0.15 \\
0.10\end{array}$ & $\begin{array}{l}24.77 \\
18.60 \\
15.53\end{array}$ \\
\hline
\end{tabular}




\begin{tabular}{lrrrrr}
\hline & $\begin{array}{r}\text { Client- } \\
\text { consultant } \\
\text { relationship }\end{array}$ & $\begin{array}{r}\text { Financial } \\
\text { and } \\
\text { contractual } \\
\text { concerns }\end{array}$ & $\begin{array}{r}\text { Delivery of } \\
\text { expectations }\end{array}$ & $\begin{array}{r}\text { Orientation } \\
\text { and } \\
\text { competence } \\
\text { of }\end{array}$ & $\begin{array}{r}\text { Ethics in } \\
\text { consultant } \\
\text { behaviour }\end{array}$ \\
\hline Chi-Square & 0.47 & 2.05 & 2.94 & 10.64 & 4.91 \\
consultants & \\
df (2-tailed) & 2 & 2 & 2 & 2 & 2 \\
\hline
\end{tabular}

* $\mathrm{p}<0.05$

\section{DISCUSSION}

From the findings is clear that the principal research objective of the study was achieved, which was to assess clientconsultant relationship considerations in relation to ethics within the management consulting profession. Five ethical dimensions were tested, namely client-consultant relationship, financial and contractual concerns, delivery of expectations, orientation and competence of consultants, and ethics in consultant behaviour.

In terms of the response rate, although consultants may have time or location constraints, the fact that responses could be emailed should have negated these constraints. Therefore, the low response rate may indicate a general lack of interest in, knowledge or understanding of ethics within the consultancies surveyed. Certainly the responses around the existence of codes of ethics within the consultancies indicate that the majority of consultants were not aware or unsure if codes of ethics even existed.

The differences found in the mean ranks between consulting firms in relation to ethical consultant behaviour, emphasise Paine's (1994) suggestion that ethical differences are often related to the organisation's leadership, the organisation culture, the organisation's ethics and its performance management. Although culture and performance management were not directly assessed in the research, it is clear from the results reported that senior management commitment has an impact on all five of the ethical dimensions tested, implying that where there is senior management commitment increased ethical behaviour appears to be exhibited.

Further, these findings around senior management commitment support the views expressed by Johannessen Ims (1995), that leadership within consulting not only has to face ethical issues specific to top management, such as what they are trying to maximise, whose interests they are trying to serve, what the external consequences will be and how one should manage the choices and trade offs, but also have to manage the ethical behaviour within their own consultancy and in relation to client -consultant relationships. Further, the results regarding senior management support Guy's (1990) view that ethical organisations need leaders that establish ethical practices and promote norms that encourage ethical behaviour in their organisations, as well as having a critical mass of ethically responsible individuals and leaders who behave ethically and serve as ethical role models for others to emulate. The results further confirm Paine's (1994) suggestion that management-led commitment to ethical values contributes to increased competitiveness, positive workforce morale and solid sustainable relationships with the company's key constituencies. Therefore, it is apparent that senior management commitment is imperative to the enforcement of ethical standards and behaviour.

From the results pertaining to the differing mean ranks of job levels compared across the five ethical dimensions, senior management and consultant levels perceive ethical behaviour, especially around the dimensions of financial and contractual concerns and the orientation and competence of consultants, to be higher than the other groupings. In terms of the consultant level, this could result from a lack of involvement in the financial aspects of the business as this level of consultant is rarely involved in the financial management of projects. In terms of the senior management levels, these perceptions may result from the fact that the consultancy may have ethical guidelines in place but that these are not communicated or implemented appropriately. As a result, senior management may believe that ethical guidelines and practices are in place, when the reality may be different and appropriate norms, processes or systems may not support ethical practices.

The results further indicate that when a code of ethics exists and is implemented, ethical behaviour of consultants may increase. The mean ranks indicate some level of inconsistency in terms of the implementation or communication of codes of ethics within the consultancies. In light of this, and in line with the views held by Guy (1990) and Newman (1993), it appears that codes of ethics provide only limited guidance for consulting practices and as a result consultants bear a heavy personal responsibility for the consequences of their professional actions and decisions. Obviously there are consequences for consultancies that just depend on the consultant's sense of responsibility for making ethical decisions, which allows human personality based, or ad hoc, decisions around ethical considerations.

In light of this finding, and in support of the suggestions of Bowie and Duska (1990), there are obvious but limited benefits from implementing a code of ethics. These include motivation through peer pressure, provision of guidance in ethically ambiguous situations, guidance in terms of behaviour and that the implementation of a code of ethics is clearly in the interest of the business itself. Potential issues may arise when implementing a code of ethics including issues around enforcement, interpretation, leadership commitment and sponsorship. As a result it is imperative that any code of ethics should incorporate professional standards, expectations of individual behaviour, corporate values and behaviour patterns, and fundamental values. This in turn needs to be reinforced by appropriate corporate programmes including communication, training and guidelines on corporate values and behaviour patterns. The achievement of high ethical standards should not just be about avoiding major problems or preventing serious misconduct, but is, according to the suggestion of Batchelor (1995), about the multitude of decisions that consultants take day-to-day involving judgement and choice. This infers that in order to change individual behaviour there also needs to be a careful recruitment selection process and once the consultant is employed appropriate role models and development be provided.

The findings that orientation and competence of consultants are affected by job level, senior management commitment and the existence of a code of ethics, indicate the importance of not underestimating this ethical dimension in the overall ethics process. This supports the view that there is a relation between appropriate ethical behaviour and the recruitment and selection process, which impacts on both the overall orientation of the consultant and the consultancy having appropriately skilled consultants (Batchelor, 1995; Paine, 1994). In the recruitment and selection process both ethics and job skills should be considered equally important in determining an individual's competence and suitability for employment. This should obviously be supported by appropriate ethically based training and performance management, specifically regarding self-governance aspects of ethical behaviour and conduct.

It can concluded that consultancies could put in place numerous mechanisms to consistently guide ethical behaviour within the 
organisation and in the client-consultant relationship. These could include appropriately communicated and implemented ethical guidelines, visible senior management commitment, ethical behaviour role modelling, training, and appropriate performance management, as well as repercussions for non-compliance to set ethical standards. Further, ethics should be incorporated into the corporate values of the organisation and should be driven through such value programmes. However, it should also be noted that in the client-consultant relationship, the client also has ethical responsibilities and as a result it is imperative that the consultancy formalise the ethical elements of the contractual negotiations, and that all ethically related considerations in this relationship should be discussed and defined during this contracting process; thereby ensuring an ethically sustainable and mutually beneficial clientconsultant relationship.

Although the organisation or consultancy needs to take responsibility for driving ethical behaviour within the practice, within the client-consultant relationship and at the individual consultant level, there would be obvious benefits in ethical behaviour and parameters being developed at the management consulting profession level. The IMC could take further responsibility for developing ethical behaviour in consultancies, through mechanisms such as providing training in ethical standards to consultants, promoting membership and acting as a body that clients can take issues for resolution similar to other professional bodies. Implementation of these mechanisms could develop greater credibility for the management consulting profession.

As previously mentioned, training is imperative to sustainable ethical behaviour in consultancies. Both consultancies and relevant professional bodies play a major role in providing appropriate training, which should include at the very least ethical training in the induction programmes used by most consultancies. However, academic institutions could also play a significant role in developing knowledge of ethical behaviour through promoting awareness of the need for and implementation of ethical parameters within organisations.

A need for research that expands on the information gleaned in this article could be valuable. Similar research could be conducted that either has a larger sample but within the same group of consultancies, or which could be conducted across a broader range of management consultancies. This could provide further information around differences between consultancies, differences in ethical parameters or codes, differences in senior management commitment and in perceived ethical behaviour. Given this context, further research could also take a qualitative approach, including indepth interviews and discourse analysis, which might provide a greater level of detail around ethical behaviour and issues within the consultancy and the client-consultant relationship. Interviews could be conducted with both the consultants and clients thereby gaining perspectives from both parties involved in the provision of consulting services and the inherent relationship between these two parties.

\section{ACKNOWLEDGEMENT}

The authors would like to thank Riëtte Eiselen and Janes du Toit of Statcon at RAU, for their professional service and valuable contribution regarding the data analysis of this project.

\section{REFERENCES}

Allen, J. \& Davis, D. (1993). Assessing some determinant effects of ethical consulting behaviour: The case of personal and professional values. Journal of Business Ethics, $12,449-458$
Allnutt, J.D. (1991). The corporate image of management consulting firms. Unpublished MBA. Johannesburg: University of the Witwatersrand.

Arbose, J. (1987). Agents of change are becoming the victims of change. International Management, 42, 35-40.

Bader, G. \& Stich, T. (1993). Building the consulting relationship. Training \& Development Journal, June, 55-60.

Barcus, S.W. \& Wilkinson, J.W. (1986). Handbook of management consulting services. New York: McGraw-Hill.

Batchelor, P. (1995). The rise of consultancy - ethical demands and requirements. In H. von Weltzien Hoivik \& A. Føllesdal (Eds.). Ethics and consultancy: European perspectives. Dordrecht: Kluwer Academic.

Bellman, G.M. (1990). The consultant's calling. San Francisco: Jossey-Bass.

Block, P. (1981). Flawless consulting: A guide to getting your expertise used. Austin, Texas: Learning Concepts.

Bowie, N.E. \& Duska, R.F. (1990). Business ethics (2nd ed.). Englewood Cliffs, N.J.: Prentice-Hall.

Brown, H. (1996). Pragmatic efforts and the new consultant. Total Quality Environmental Management, 5(4), 1-6.

De George, R.T. (1986). Business ethics (2nd ed.). New York: MacMillan.

De George, R.T. (1989). There is ethics in business ethics; but there is more as well. Journal of Business Ethics, 8, 337-339.

Erasmus, M. \& Schepers, J.M. (1997). Perceptions of the dimensions of work success of management consultants in South Africa. Journal of Industrial Psychology, 23(3), 27-35.

Foust, D. (17 July 2000). First, sue all the consultants. Business Week, 3690, 96.

Greiner, L.E. \& Metzger, R.O. (1983). Consulting to management. Englewood Cliffs, N.J.: Prentice-Hall.

Guy, M.E. (1990). Ethical decision making in everyday work situations. Westport, Connecticut: Quorum.

Hammond, K., Kelly, K. \& Thurston, K. (1994). Rethinking work. Business Week, October, 40-49.

Harding, C.F. (1995). Finessing the sale. Journal of Management Consulting, 8(4), 53-55.

Harvey, D.F. \& Brown, D.R. (1996). An experiential approach to organisation development ( $5^{\text {th }}$ ed.). Englewood Cliffs, N.J.: Prentice-Hall.

Hegarty, W.H. \& Simms, H.P. (1978). Some determinants of unethical decision behaviour: An experiment. Journal of Marketing Research, 16, 451-457.

Johannessen Ims, K. (1995). The consultant-client relationship: Personal autonomy and development through dialogue. In H. von Weltzien Hoivik \& A. Føllesdal (Eds.). Ethics and consultancy: European perspectives. Dordrecht: Kluwer Academic.

Kehayas, A. (1999). The changing face of management consulting. Management Today, August, 34-36.

Kubr, M. (Ed.). (1988). Management consulting: A guide to the profession ( $2^{\text {nd }}$ ed.). Geneve: International Labour Organisation.

Linafelt, T. (1997). Bad consultants can make company woes even worse. Wichita Business Journal, 12(12), 11.

McDonald, G. \& Nijhof, A. (1999, March). Beyond codes of ethics: an integrated framework for stimulating morally responsible behaviour in organisations. The Leadership \& Organization Development Journal, 133-146.

Moore, G.L. (1984). The politics of management consulting. New York: Praeger.

Newman, J.L. (1993). Ethical issues in consultation. Journal of Counseling and Development, 72(2), 148-158.

Paine, L.S. (1994). Managing for organizational integrity. Harvard Business Review, March-April, 106-117.

Parsons, R.D. (1996). The skilled consultant: A systematic approach to the theory and practice of consultation. Needham Heights: Allyn \& Bacon

Price, C.R. (1991). A new national program for consulting. Journal of Management Consulting, 6(2), 17-22. 
Savion, S.A. (1998). Build client relationships on foundation of ethics. Washington Business Journal, 16(38), 38.

Shaw, W.H. (1991). Business ethics. Los Angeles: Wadsworth.

Shay, P. (1965). How to get the best results from management consultants. New York: Association of Consulting Management Engineers.

Shays, E.M. (1988). Straight talk about management consulting. Journal of Management Consulting, 4(3), 28-30.

Shays, E.M. (1996). Obedience to the unenforceable. Journal of Management Consulting, 9(2), 42-43.

Sims, R.L. (1999, April). The development of six ethical business dilemmas. The Leadership \& Organization Development Journal, 189-197.
The South African Institute of Chartered Accountants, (1992). Management Consulting. Johannesburg: Penrose.

Van Rooyen, M. (1996). Codes to distinguish consultants from con artists. People Dynamics, 14(1), 27-31.

Weisbord, M.R. (1994). Toward third-wave managing and consulting. In W.L. French, C.H. Bell \& R.A. Zawacki (Eds.) Organization development and transformation. Chicago, Illinois: Irwin.

Wessel Ganzevoort, J. (1995). Ethical issues in consultancy. In H. von Weltzien Hoivik \& A. Føllesdal (Eds.). Ethics and consultancy: European perspectives. Dordrecht: Kluwer Academic. Wooldridge, A. (22 March 1997). The perfect product? The Economist, 342(8009), 21. 